\title{
The relationship between cell-phone addiction with the academic achievement motivation and academic performance of students in Khash Baluchestan
}

\author{
Somayeh Shahroudi ${ }^{1}$, Freydoon Soltani $^{2}$, Narges Nouri ${ }^{3}$, Afsaneh Rigi $^{4}$ \\ 1-Instructor, Faculty member, Department of Statistics and Epidemiology, Health Promotion Research Center, \\ Zahedan University of Medical Sciences, zahedan, iran. ORCID: 0000-0002-0552-1441 \\ E-mail: s.shahroodi@zaums.ac.ir \\ 2-Student, Department of surgery room, Zahedan University of Medical Sciences, Student Research \\ Committee, Khash Health High Education Complex, zahedan, iran. ORCID: 0000-0003-1149-1442 \\ 3-MSc in Health Education, Departman of puplic health, Zahedan University of Medical Sciences, asistant of \\ Education and Research Khash Health High Education Complex, zahedan, iran. ORCID: 0000-0002-4852-7835 \\ 4- MSc in Internal and surgical nursing, Departman of nursing, Zahedan University of Medical Sciences, \\ education expert of Khash Health High Education Complex, zahedan, iran. ORCID: 0000-0002-4870-6737
}

Received: $26 / 09 / 2018$

Accepted: 22/12/2018

\begin{abstract}
Introduction: Excessive use of cell-phones can lead to dependency and have negative consequences for students and their academic achievement motivation.

Aim: This study has carried out to investigate the relationship between cell-phone and students' academic achievement motivation.

Method: This descriptive study was carried out with 300 students from Khash Higher education centers. The sampling method was classified-proportional. The instrument for data collection was a Savari's moderated questionnaire on cell-phone addiction and Hermann's academic achievement Motivation Questionnaire. Collected data were analyzed using SPSS software (version 21), Pearson correlation coefficient, independent t-test, one-way ANOVA and regression.
\end{abstract}

Results: The mean (SD) of the cell-phone addiction score was 48.28(12.27) and the mean (SD) of the student's academic achievement motivation score 79.9(8.45). According to the Pearson correlation test, there was a significant and negative correlation between cell- phone addiction and students' academic achievement motivation $(\mathrm{r}=-0.33, \mathrm{p}<0.001)$.

Conclusion: According to the results, it is necessary for educational authorities to develop and plan effective programs to increase students' awareness of the negative consequences of cell-phone.

Keywords: Mobile addiction, Motivation progress, Academic Performance, Student

How to cite this article : Shahroudi, S., Soltani, F., Nouri, N., Rigi, A. (2019). The relationship between cell-phone addiction with the academic achievement motivation and academic performance of students in Khash Baluchestan. Shenakht Journal of Psychology and Psychiatry. 2019; 5 (6): 57-70 .URL :http://shenakht.muk.ac.ir/article-1-563-fa.pdf

Copyright (C) 2018 the Author (s). Published by Kurdistan University of Medical Sciences. This is an open access article distributed under the terms of the Creative Commons Attribution-Non Commercial License 4.0 (CCBY-NC), where it is permissible to download, share, remix, transform, and buildup the work provided it is properly cited. The work cannot be used commercially without permission from the journal. 


\title{
بررسى رابطه وابستكى اعتياد تونه به تلفن همراه با انكيزه يشيرفت و عملكرد تحصيلى دانشجويان شهر خاش منطقه بلوجستان
}

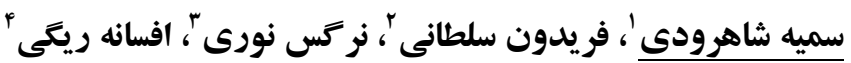

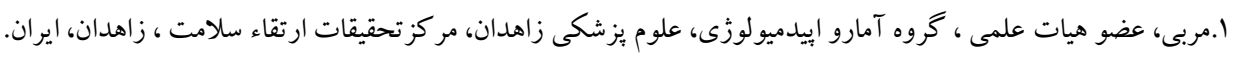
ايميل:r.shahroodi@zaums.ac.ir

ז.دانشجو، گروه اتاق عمل، دانشگاه علوم يزشكى زاهدان، كميته تحقيقات دانشجوئى،مجتمع آموزش عالى سلامت خاش، زاشي، زاهدان، ايران.

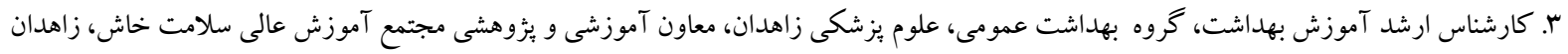

F. كارشناس ارشد يُرستارى داخلى و جراحى، گروه يرستارى، علوم بزشكى زاهدان، كارشناس آموزش مجتمع آموزش عالى سلامت خاش، زاهدان، ايران.

مقدمه: استفاده مفرط از تلفن همراه مىتو اند منجر به وابستخى شود و بيامد منفى بر دانشجويان و انخيزش بيشرفت آنان داشته

هدف: اين مطالعه با هدف بررسى ارتباط بين اعتياد به تلفن همراه و انخيزه بيشرفت در دانشجويان انجام شده است. روش: مطالعه توصيفى حاضر با شر كت ..r نفر از دانشجويان مراكز آموزش عالى شهرستان خاش انجام شد. روش نمونه گيرى

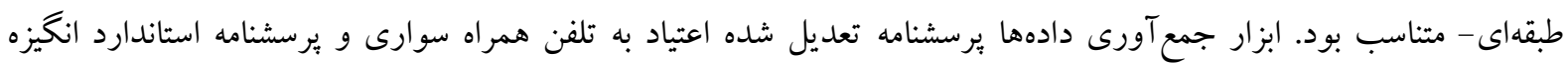

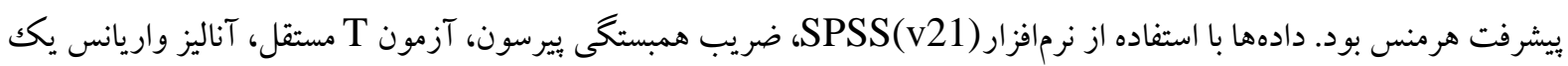
طرفه و رگرسيون تحليل شد.

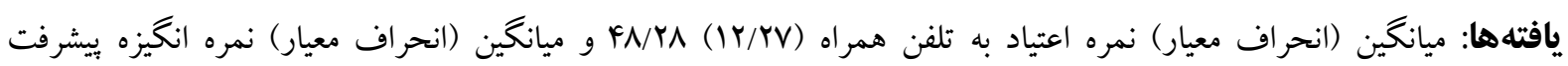

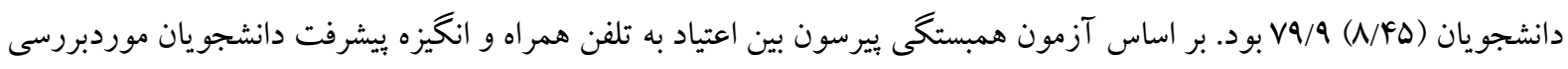
ارتباط منفى و معنى ار مشاهده شد (p) نتيجه كيرى: با توجه به نتايج لازم است مسئولين آموزشى جهت افزايش آكاهى دانشجويان از بيامدهاى منفى تلفن همراه برنامهاى كار آمد تدوين و اجرا نمايند. كليدوازه ها: اعتياد به تلفن همراه، انگيزه بيشرفت، عملكرد تحصيلى، دانشجو 
استفاده مفرط و بيش ازحد آن بدون آكاهى صورت

مقدمه

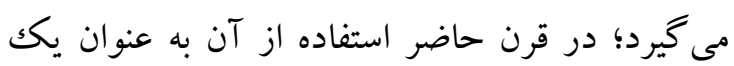

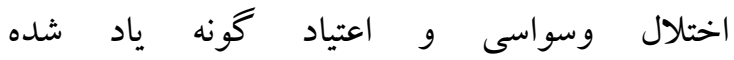
است(سوارى، اسجب1). اعتياد به تلفن همراه در فهرست انواع اعتيادات امروزىDSM-5نيست، به همين دليل در تشخيص، بررسى و درمان اعتياد به تلفن همراه

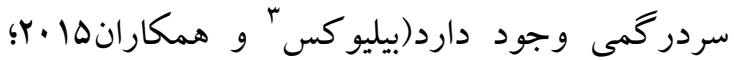

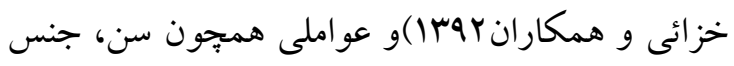

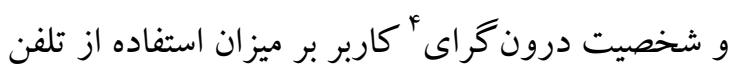

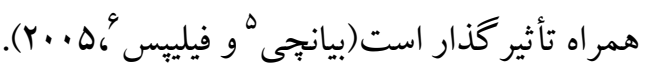
از نشانهاى وابستگى و اعتياد به تلفن همراه، استفاده مفرط، عدم توانايى در كنترل استفاده از آن، تعارضات خانوادگى، طولانى بودن و بنهان كردن مكالمات از

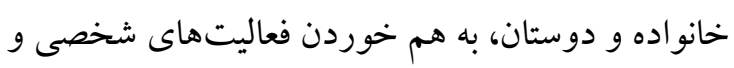
اجتماعى، حواس برتى، احساس نياز به مكالمه تلفنى يا بيام كوتاه همجنين احساس بوجى و اضطراب ناشى از

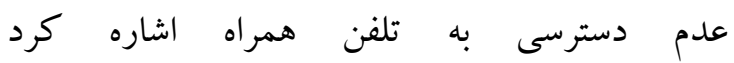

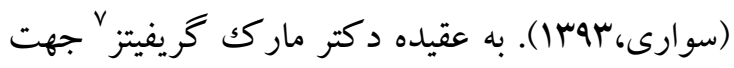
ارزيابى اعتياد به تكنولوزى و فناورى همجيون اينترنت، دو شاخص مهم يعنى استفاده بيش از حد از آن و ولم

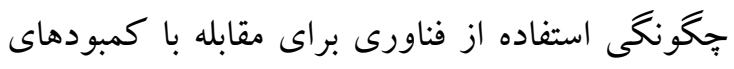

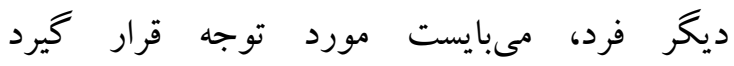

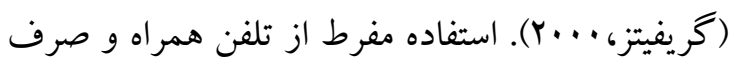
زمان بيش از حد معمول، افزايش انزواى اجتماعى رادر بردارد و اين خود باعث كاهش سلامت روان و افزايش

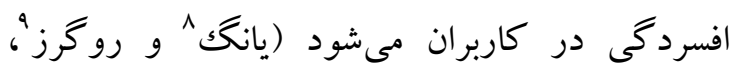

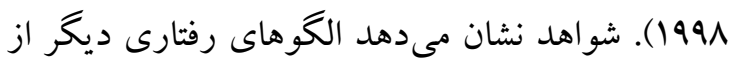
جمله بيدار ماندن در شب، اشتغال به تبادل بيام و

\footnotetext{
${ }^{3}$ Billieux

${ }^{5}$ Bianchi

${ }^{6}$ PHilips

${ }^{7}$ Griffiths

${ }^{8}$ Young
}

${ }^{1}$ ISHii

${ }^{2}$ Choliz

\section{Hii}

تلفن همراه از زمان ورودش، دهه •م تاكنون، به بخش

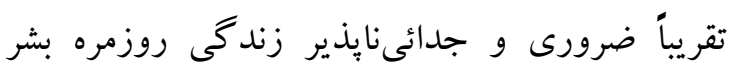
تبديل شده است، بهطورى كه در خند دهه اخير از رشد

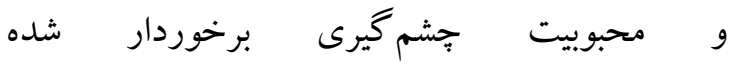

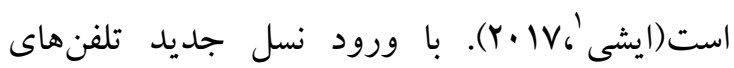
هوشمند و اتصال آن به اينترنت، انقلابى در بين

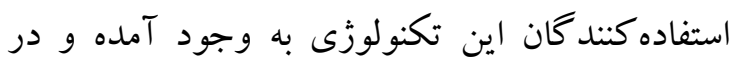
سالهاى اخير تعداد مشتركين آن به علت راحتى و ودود

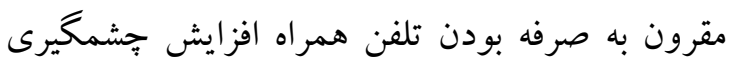

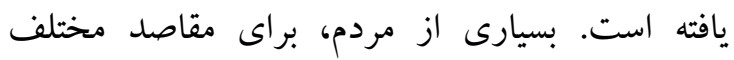

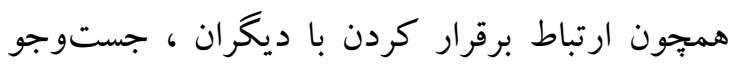

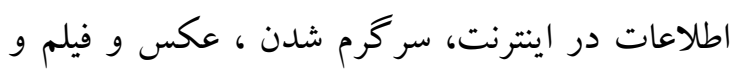
مطالعه كردن از آن استفاده مى كنند(صالحان و و نكهبان، بوسا). جذابيتها و توسعه نو آورىهاى تلفن همراه بهخصوص در حوزه نرمافزارهاى كاربردى ييامرسانها و شبكههاى اجتماعى سبب كرايش بيش از بيش افراد به خصوص جوانان و نوجوانان به اين تكنولوزى شده است و با وجود سابقه فعاليت كوتاهى كه داشتهاند كاربران بىشمارى را جذب خورد بود

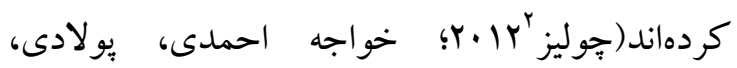
بحرينى .0هوب1). علىرغم تمام نكات مثبت تلفن همراه، استفاده نامتعارف آن ضمن افزايش هزينهها، در فعاليتهاى روزمره و روابط بين فردى كاربر، تداخل و تغيير ايجاد كرده و حتى سلامت جسم و روان او را تحت تأثير قرار مى دهد (جوليز، Y Y.Y).استفاده نامعقول و افر اطى از تلفن همراه سبب ظهور يديدهاى به نام اعتياد به تلفن همراه شده است(جان آبادى ،هوس1). اعتياد به تلفن همراه يكك اعتياد غير داروئى و رفتارى است كه گاهى اوقات التهات 
منفى دارد به عبارتى ميزان توجه و درگيرى تحصيلى دانشجويان با افزايش ميزان استفاده از تلفن همراه كاهش مىيابد كه اين خود بر ييشرفت تحصيلى دانشجويان تأثير گذار است (صيامى، رستمى و سالارى،

.$(1) 99$

در مورد دانشجويان انگيزه بيشرفت در تحصيل و

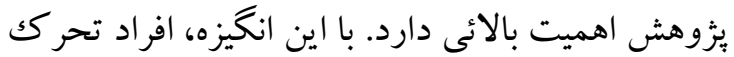

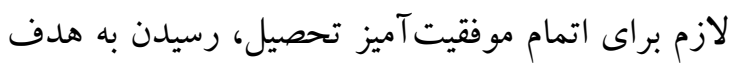
يا دستيابى به درجه معينى از شايستگى در زمينه كارى خود و يثزوهش را دنبال مى كنند تا در نهايت بتواند

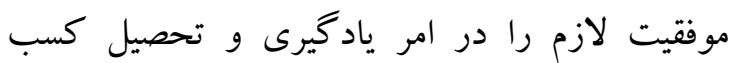

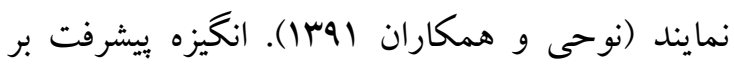
اساس دو مفهوم رقابت و برترىجوئى تعريف مى شود؛

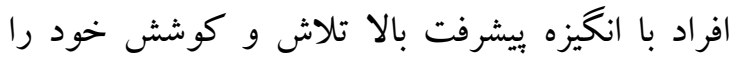
جهت رسيدن به اهداف متعالى به كار مى گيرند (اكبرى، وAץ|). روان شناسان و مدرسان بر نقش و

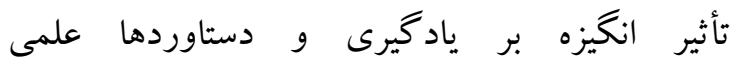

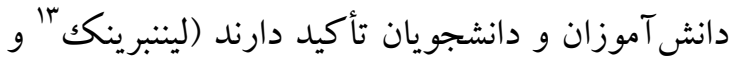

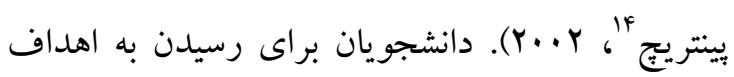

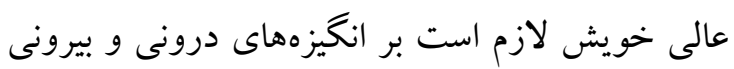
كه خود متأثر از خانواده، دوستان و محيط است، متمر كز شوند (احمد، 9. . (Y). درحالى كه مطالعات نشان مىدهد كه تمامى مؤلفههاى فرسودگى تحصيلى در دانشجويان با اعتياد به تلفن همراه در ارتباط و قابل

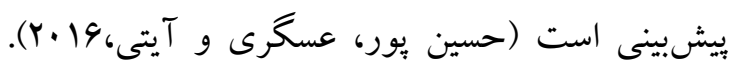

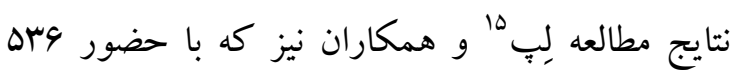
دانشجوى كارشناسى ارشد در ايالاتمتحده با استفاده از مدل ركرسيون خند سطحى و كنترل متغيرهاى دمو گرافيك و مخدوش كننده انجام شد، نشان داد كه رئر بين استفاده از تلفن همراه و عملكرد و ويشرفت
وابستگى عاطفى كه در ذهن كاربر ايجاد مىشود به طورى كه اين افراد معتقدند بدون تلفن همراه قادر به زندگى نيستند، با استفاده مفرط از تلفن همراه مرتبط است (رضوى زاده و همكاران، وهبr 1). ازجمله كاربران مهم اين تكنولوزى، دانشجويان مىباشند، امكانات و تسهيلات موجود در تلفن همراه، همجون دسترسى سريع به منابع و اطلاعات و وجود شبكههاى اجتماعى، ياد گيرى دانشجويان را متحول ساخته است (فقيه آرام، ابراهيمى، ضرغام هوسبا). دانشجويان از جمله كاربرانى هستند كه ضمن روبرو شدن با مشكلات آموزشى، اقتصادى، تغييرات فرهنگى و اجتماعى در دوران تحصيل، در معرض آسيب هاى ناشى از استفاده بيش از حد تلفن همراه قرار دارند

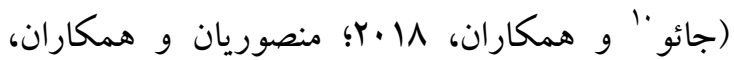

(Irar مطالعات نشان مىدهد كه با افزايش ميزان استفاده از تلفن همراه، وابستگى روانى دانشجويان به تلفن همراه

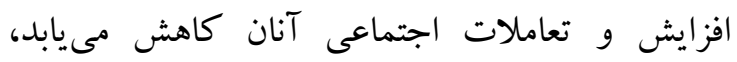
همجنين اين افزايش استفاده باعث افزايش افت تحصيلى در دانشجويان شده است (فقيه آرام و

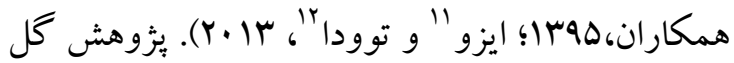

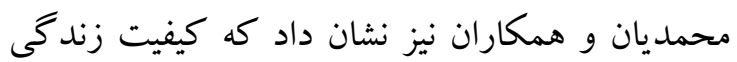
دانشجويان با استفاده مفرط از تلفن همراه ارتباط منفى

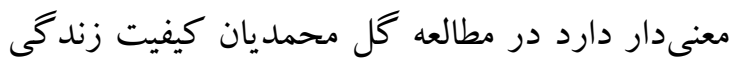
در ابعاد سلامت عمومى، سلامت روان و عملكرد

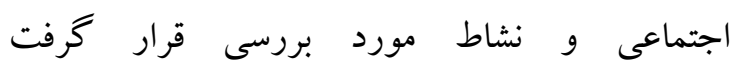

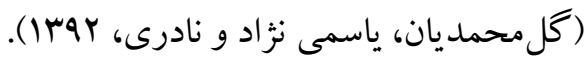

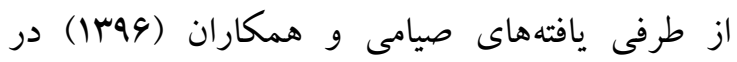
دانشجويان دانشگاه بيرجند نشان داد كه افزايش ميزان وان وان استفاده از تلفن همراه بر دامنهى توجه دانشجويان تأثير 
ترتيب كه شهر خاش بر حسب دانشگاه ها به جهار طبقه تقسيم شد سيس از هر طبقه به تناسب تعداد كل دانشجويان در حال تحصيل آن طبقه، نمونه به تصادف

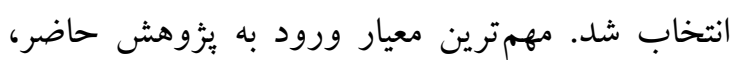
دانشجوى مشغول به تحصيل در يكى از مراكز آموزش عالى شهر خاش و رضايت آكاهانه دانشجويان جهت شركت در مطالعه بود همجنين برسشنامهى دانشجويانى كه به دلايل مختلف ناقص برشده بود از مطالعه خارج شدند. پس از هماهنگ با مسئولين دانشخاهها و توجيه دانشجويان در زمينه بثزوهش، كسب رضايت از آنان با

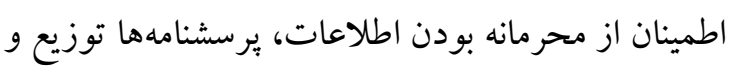
يس از تكميل جمع آورى شدند.

ابزار ابزار بز وهش جهت جمع آورى اطلاعات يرسشنامه بود كه در سه بخش كلى شامل سؤالات دمو كرافيك ترو دانشجويان موردمطالعه، يرسشنامه اعتياد به تلفن همراه و برسشنامه انخيزه بيشرفت تحصيلى بود. سؤالات

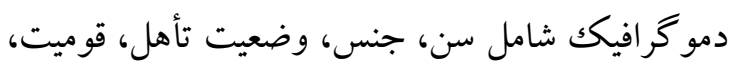
وضعيت اقتصادى، خو ابگًاهى بودن، نوع دانشگًاه، رشته تحصيلى و معدل آخرين ترم تحصيلى كه بهصورت خود گزارش دهى تكميل شد. يرسشنامه اعتياد به تلفن همراه: براى جمع آورى اطلاعات مربوط به اعتياد به تلفن همراه دانشجويان از يرسشنامه تعديلشده اعتياد به تلفن همراه كه توسط

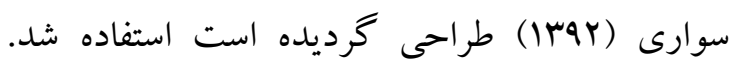
يرسشنامه تعديل شده حاضر، از \ا گويه و سه مؤلفه به

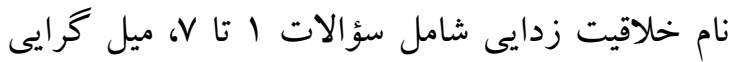
شامل سؤالات ^ 1 تا Y I و احساس تنهايى شامل سؤالات سا تا \1 است. سؤالات برسشنامه در مقياس ليكرت ينج درجهاى با درجات هر گز، به ندرت، كاهى اوقات، معمولاً و اكثر اوقات طراحى شده است. شيوه
تحصيلى دانشجويان ارتباط منفى و معنى دار وجود

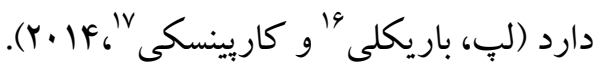
با توجه به اين مهم كه جامعه براى ييشرفت و رفع موانع آن، بسيار وابسته به نيروى جوان سالم و برانكيزه به بصوص دانشجويان است، بنابراين بررسى تأثيرات منفى تكنولوزىهاى جديد همجيون تلفن همراه هوشمند بر انخيزه بيشرفت و و عملكرد تحصيلى دانشجويان لازم است. بثوهش حاضر براى بِاسخ به سؤالات زير در

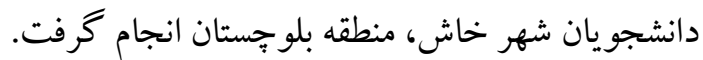
شيوع اعتياد به تلفن همراه در دانشجويان شهر خاش

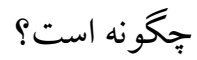
آيا بين اعتياد به تلفن همراه و انگيزه ويشرفت دانشجويان ارتباط وجود دارد؟ آيا بين اعتياد به تلفن همراه و عملكرد تحصيلى دانشجويان ارتباط وجود دارد؟

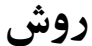

مطالعه حاضر يكك مطالعه توصيفى- همبستخى از نوع

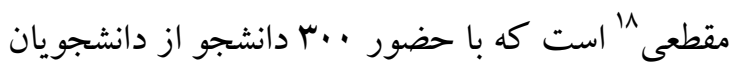
دانشگاههاى شهر خاش شامل دانشگاه آزاد، ييام نور، مجتمع آموزش عالى سلامت و دانشكده صنعت و

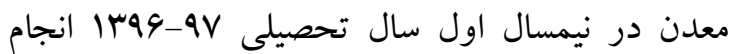
شد. شهرستان خاش يكى از •ا شهرستان استان سيستان و بلوجستان و در جنوب شرقى زاهدان واقع شده است. با توجه به مشخص بودن تعداد كل دانشجويان شهر كه

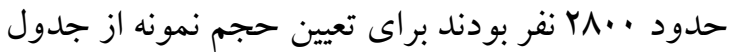

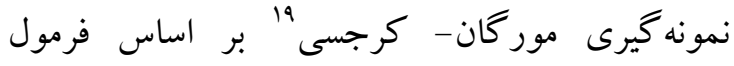
كو كران، استفاده شد. جهت انتخاب نمونه ها از روش نمونه گيرى طبقه اى -متناسب استفاده شد. بدين

\footnotetext{
${ }^{16}$ Barkley

${ }^{17}$ karpinski

${ }^{18}$ cross-sectional

${ }^{19}$ Morgan-Krejcie
} 
اه تا هF به عنوان سطح انگيزه بيشرفت متوسط و نمرات بين هو تا 119 به عنوان سطح انخيزه بيشرفت بالا در نظر كرفته شد. روايى محتوا و وِايايى پرسشنامه انخيزه بيشرفت در مطالعات متعدد تائيد شده است بـائ برست

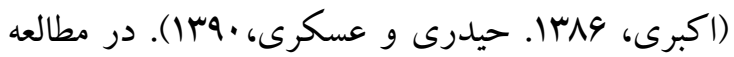
حاضر نيز يايايى آن با استفاده از ضريب آلفاى كرونباخ

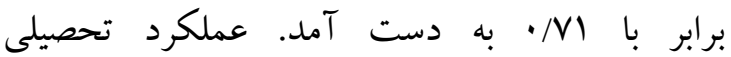
دانشجويان نيز با استفاده از معدل آنان ارزيابى شد. ״س از جمع آورى برسشنامه ها و كدبندى متغيرها، اطلاعات در نرم افزار SPSS(V21 ثبت و آناليز در سطح معنى دارى ينج درصد انجام شد. نرمال بودن توزيع مشاهدات نمونه استخراجى با استفاده از آزمون كولمو گروف- اسميرنوف بررسى شد. براى بررسى همبستخى بين متغيرهاى كمى يُزوهش از آزمون

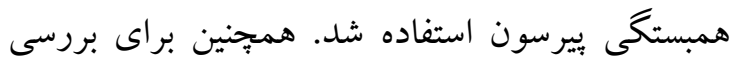
متغيرهاى كمى به تفكيك متغيرهاى كيفى دو سطحى از آزمون هاى T مستقل و در ساير متغيرهاى كيفى از آناليز واريانس يك طرفه (ANOVA) بـ استفاده شد. در نهايت براى بيش بينى تغييرات متغير وابسته يعنى انخيزه بيشرفت دانشجويان بر اساس اعتياد به تلفن همراه از رگرسيون خطى تكك متغيره استفاده شد.

\section{يافته ها}

در اين ئزوهش ·.ب برسشنامه توسط دانشجويان تكميل كرديد كه شش يرسشنامه ناقص از مطالعه حذف شد. 91/9 درصد شر كت كنند گان را دانشجويان

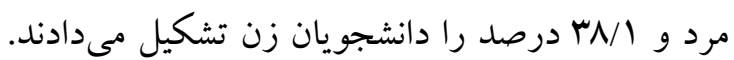
ميانخين (انحراف معيار) سنى دانشجويان (r/r) ه با حداقل 1 1 و حداكثر •F سال بود. Fr/ F درصد دانشجويان ساكن خوابگاههاى دانشجويى و و درصد غير خوابكاهى بودند. ه/ه درصد دانس دانشجويان
نمره كذارى سؤالات نيز به صورت هر گز با نمره 1 تا اكثر اوقات با نمره ه است. حداقل و حداكثر نمره كسب شده از خرده مقياس خلاقيت زدايى Vو هاّ، از

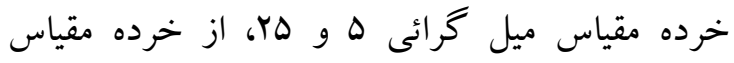
احساس تنهايى و و ·ب و از كل برسشنامه اعتياد به تلفن همراه، 1) و و9 است. در برسشنامه اعتياد به تلفن همراه كسب نمره بالاتر نشان دهنده وابستكى بيشتر است.

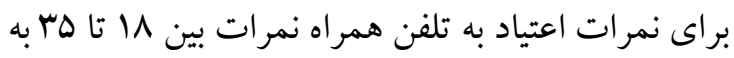

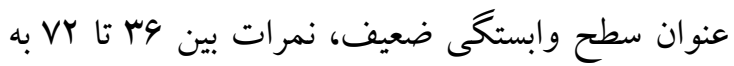

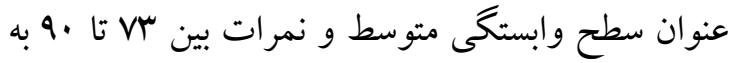

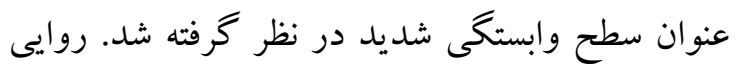
يرسشنامه تعديل شده اعتياد به تلفن همراه با استفاده از اعتبار محتوا تعيين و توسط اعضاى هيات علمى تأييد

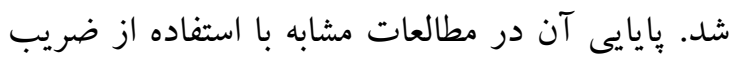

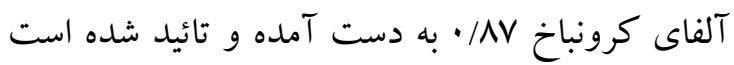

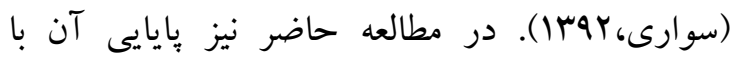
استفاده از ضريب آلفاى كرونباخ س/N/ به دست آمد. يرسشنامه انكيزه بيشرفت: جهت جمع آورى اطلاعات مربوط به انخيزه ييشرفت از يرسشنامه استاندارد انكيزه

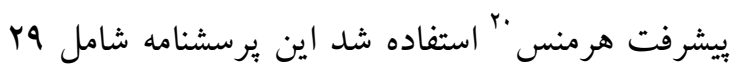
سؤال F كزينهاى است. سؤالات به صورت جملات ناتمام طراحى شده است و كزينه ها بر حسب اينكه

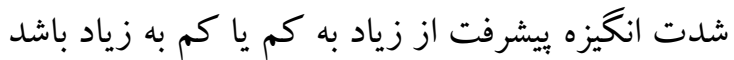
نمره داده مى شود با توجه به اين مهم برخى از سؤالات به صورت مثبت و برخى به صورت منفى ارائه شده

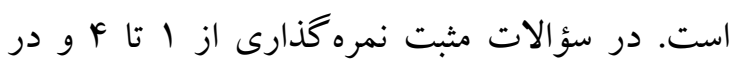
سؤالات منفى بالعكس است. دامنه تغييرات نمرات از

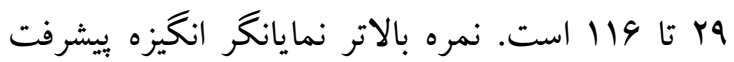

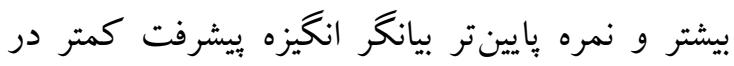

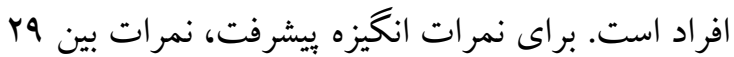
تا •ه به عنوان سطح انخيزه بيشرفت ضعيف، نمرات بين 
مرد، افراد متأهل بثزوهش و دانشجويان با وضعيت

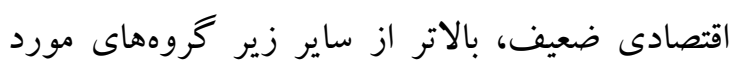

$$
\text { بررسى بود. }
$$

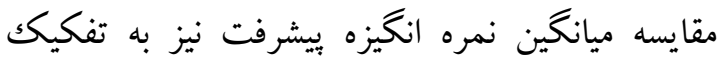
متغيرهاى جمعيتى دانشجويان نشان داد كه اختلاف مئس مشاهدهده تنها براى متغير قوميت دانشجويان به

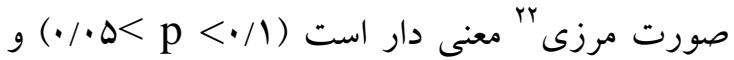
انخيزه ويشرفت در دانشجويان با قوميت كرد و لر بيشتر از دانشجويان فارس و بلوج است. اختلاف ميانگين نمره انگيزه بيشرفت در متغيرهاى جنسيت، وضعيت تأهل، محل اسكان، وضعيت اقتصادى و نوع دانشگاه معنىدار نشد (ه)/ (p) و و بيشترين ميزان انخيزه ييشرفت مشاهدهده در دانشگًاهاى موردبررسى مربوط به دانشكده صنعت و معدن است (جدول (1).
داراى قوميت فارس، \&/9 د درصد داراى قوميت بلوج و

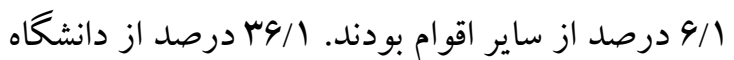

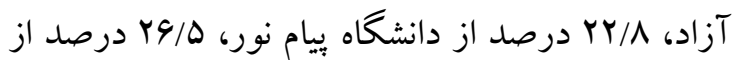
مجتمع آموزش عالى سلامت و 1F/9 درصد از دانشكده صنعت و معدن در مطالعه شركت نمودند. وضعيت اقتصادى Y Y درصد دانشجويان خوب، درصد متوسط و IV/9 درصد ضعيف گزارش شده است. متوسط آخرين معدل ترم تحصيلى دانشجويان حاضر در مطالعه 19/r، با حداقل لا و حداكثر ·r بود. ميانگين (انحراف معيار) اعتياد به تلفن همراه (IY/YVV)

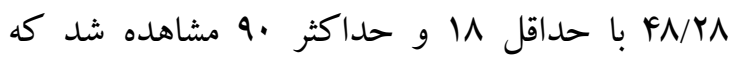
اعتياد به تلفن همراه 1ه/9 درصد در سطح ضعيف، ش 1 M درصد در سطح متوسط و •r/ درصد در سطح شديد مشاهده شد. ميانگين (انحراف معيار) انخيزه يشرفت دانشجويان نيز (N/FD / حداقل آن وها و حداكثر آن س.ا بود. انكيزه بيشرفت 9F/9 درصد دانشجويان در سطح متوسط و / /ه درصد در سطح بالا بود. نتايج آزمونهاى تى مستقل و آناليز

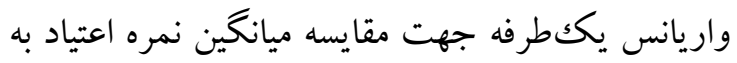

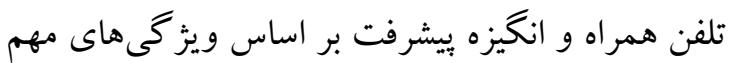
جمعيتى نشان داد كه اختلاف مشاهده شده ميانگين نمره اعتياد به تلفن همراه در متغيرهاى جمعيت شناسى تنها براى متغيرهاى وضعيت اسكان و نوع دانشگاه معنىدار است (ه•/p) در بررسى ميزان اعتياد به تلفن همراه در دانشگاهها بيشترين ميزان اعتياد به تلفن

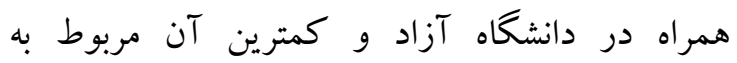
دانشكده صنعت و معدن بود همجِنين اعتياد به تلفن همراه در غيرخو ابكاهىها بيشتر از خوابگاهى ها مشاهده شد. اختلاف ميانگين نمره اعتياد به تلفن همراه برای متغيرهاى جنسيت، وضعيت تأهل، وضعيت اقتصادى و

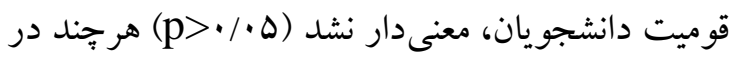
مطالعه حاضر سطح اعتياد به تلفن همراه در دانشجويان 


\begin{tabular}{|c|c|c|c|c|}
\hline سطح معنى دارى & ميانگين (انحر اف معيار) & سطح معنى دارى & ميانگين (انحراف معيار) & متغيرهاى جمعيت \\
\hline انگيزه بيشرفت & انگگيزه بيشرفت & اعتياد به تلفن همراه & اعتياد به تلفن همر اه & \\
\hline
\end{tabular}

\begin{tabular}{|c|c|c|c|c|c|}
\hline \multirow[t]{2}{*}{$\cdot / T F$} & $\Lambda \cdot / \Delta ৭(V / r Y)$ & \multirow[t]{2}{*}{$\cdot / \Delta$} & FV/G9(IT/rV) & زن - ت ان & \multirow[t]{2}{*}{ جنسيت } \\
\hline & $\vee q / \& \wedge(q / \cdot \vee)$ & & FN/GV(II/D9) & 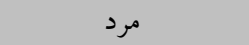 & \\
\hline \multirow[t]{2}{*}{.194} & $\Lambda \cdot / I r(\Lambda / \Delta V)$ & \multirow[t]{2}{*}{.$/ T Y V$} & $F V / G(\mid Y / Y r)$ & مجرد & \multirow[t]{2}{*}{ وضعيت تأهل } \\
\hline & $\mathrm{V} / \Delta(\Lambda / \Delta V)$ & & $\Delta \cdot / r V(I Y / Y 4)$ & متأهل & \\
\hline \multirow[t]{2}{*}{.194} & $\Lambda \cdot / 19(9 / \Lambda)$ & \multirow[t]{2}{*}{$\cdot 1 \cdot 11^{*}$} & $F q / \mid \wedge(|r / F|)$ & خوابكاهى & \multirow[t]{2}{*}{ محل اسكان } \\
\hline & $\mathrm{VQ} / \mathrm{V}(\mathrm{V} / \mathrm{TF})$ & & $₹ q / \wedge q(11 / 4 \Delta)$ & غير خوابگاهى & \\
\hline \multirow{3}{*}{$\cdot / \mathrm{NI}$} & 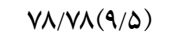 & & $F q / \cdot f(11 / \cdot q)$ & ضعيف & \multirow{3}{*}{ وضعيت اقتصادى } \\
\hline & $\Lambda \cdot / \mu F(\Lambda / Y \Delta)$ & $\cdot / \wedge \Delta$ & $F V / 99(\mid Y / 9 \Lambda)$ & متو سط & \\
\hline & $\vee \vee / \Lambda 9(\Lambda / \Gamma)$ & & FN/G. (IY/V) & خوب & \\
\hline \multirow{3}{*}{$\cdot / \cdot V$} & $\Lambda \cdot / 9(1 \cdot / \cdot r)$ & \multirow{3}{*}{$\cdot / 1 \cdot r$} & Fq/IF(Ir)Ir & 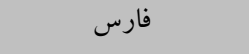 & \multirow{3}{*}{ قوميت } \\
\hline & $\vee q / F q(V / \wedge r)$ & & $F \wedge / \Delta q(\mid 1 / \wedge q)$ & بلوج & \\
\hline & $\Lambda Y / V F(r / 9 r)$ & & $\Delta r / \Delta(Q / 9)$ & ساير اقوام(كرد،،لر،...) & \\
\hline \multirow{4}{*}{$\cdot / \Delta r$} & $\vee 9 / 91(9 / 1)$ & & $0 \cdot / F F(\mid r / r F)$ & آزاد & \multirow{4}{*}{ دانشگاه } \\
\hline & $\mathrm{V} \wedge / \mathrm{r} \wedge(\mathrm{V} / \mathrm{VI})$ & $\cdot / \cdot 1 r^{* * *}$ & $F q / \wedge q(1 \cdot / F \Delta)$ & يُبام نور & \\
\hline & $\Lambda \cdot / \mathscr{q}(\Lambda / \Delta V)$ & & $F \Delta / 99(1 Y / / 0)$ & سلامت & \\
\hline & $11 / 4 \mid(\mid Y / .9)$ & & $F \Delta / r(I r / V \Delta)$ & صنعت و معدن & \\
\hline
\end{tabular}

\section{جدول r ميانكين، انحر اف معيار و ماتريس ضرايب همبستكى و سطح معنىدارى حيطه هاى اعتياد به تلفن همراه، انكيزه بيشرفت و معدل دانشجويان}

\begin{tabular}{|c|c|c|c|c|c|c|c|}
\hline $\begin{array}{c}\text { ميانكين (انحراف } \\
\text { معيار) }\end{array}$ & 9 & 0 & F & $r$ & $r$ & 1 & متغير \\
\hline $19 / \mathrm{rV}(\Delta / \mathrm{VA})$ & & & & & & 1 & خلاقيت زدايى \\
\hline$r r / Q Y(Q / \Delta)$ & & & & & 1 & $\cdot / \Delta V V^{*}$ & احساس تنهايى \\
\hline
\end{tabular}

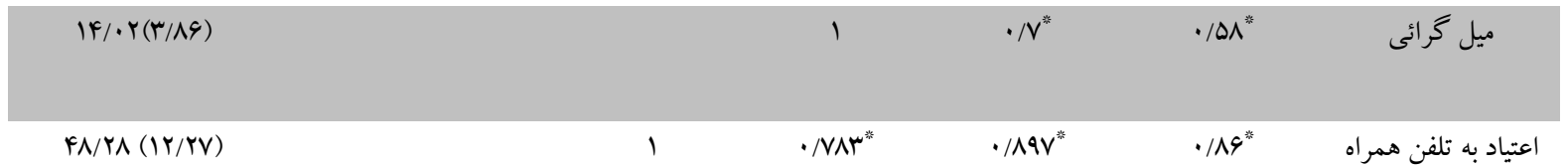

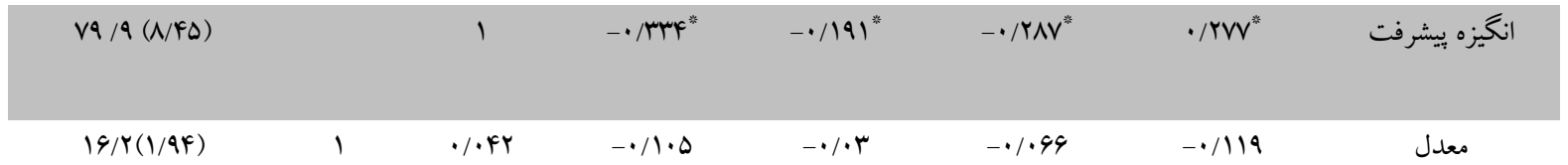




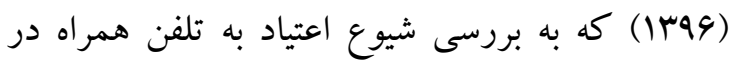
دانشجويان برستارى مى يرداخت و مطالعه تو كلى زاده و همكاران (rarا) در گناباد هم سو نيست كه احتمالاً يكى از دلايل آن مى تواند متفاوت بودن ابزار تشخيص

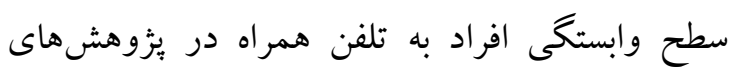
انجام شده، باشد. نتايج شيوع وابستكى اعتياد گونه به تلفن همراه در دانشجويان مطالعه حاضر حاكى از آن است كه نمى توان نسبت به اين ميزان شيوع بى تفاوت بود؛ هرجند ميزان آن نشان از وخامت مسئله نيست (موسوى و شفيق، هوسا). در تبيين علت آن مىتوان كفت كه عدم وجود امكانات تفريحى و ورزشى مناسب و درخور قشر جوان، يرشور و دانشجوى منطقه محروم شهر خاش و از طرفى جذابيتها، ظرفيتها، امكانات و قابليت دسترسى آسان و سريع به تلفن همر اه جهت بر كردن اوقات فراغت باعث گرايش و تمايل جوانان و دانشجويان منطقه به اين تكنولوزى شده است. نتايج مطالعه حاضر نشان داد كه انخيزه بيشرفت در دانشجويان با اعتياد به تلفن همراه در ارتباط است و نوع اين ارتباط معكوس است. به طورى كه در دانشجويانى كه وابستكى مفرط به تلفن همراه داشتند انكيزه يشرفت ميل به كاهش داشت اين وابستخى بر تحصيل

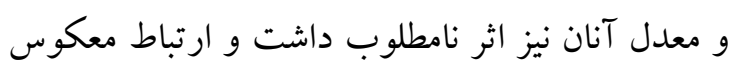
بين اعتياد به تلفن همراه با معدل و عملكرد تحصيلى دانشجويان ديده شد. اين نتايج با مطالعه حسين بور و همكاران (هوبا) كه نشان دادند بين اعتياد به تلفن همراه و اينترنت با فرسودگى تحصيلى در دانشجويان ارتباط معنى دار وجود دارد و خستكى و ناكار آمدى در تحصيل وابسته به اعتياد به تلفن همراه است، همسو است. نتايج حاضر با مطالعه عطا دخت و همكاران (سوץ|) نيز همسو است نتايج مطالعه آنان نشان داد بين اعتياد به تلفن همراه و انكيزه ويشرفت و و عملكرد تحصيلى جوانان دبيرستانى ارتباط منفى معنىدار وجود
نتايج مربوط به ضرايب همبستكى حيطهاى اعتياد به تلفن همراه و انكيزه ييشرفت نشان داد كه بين انكيزه يشرفت و اعتياد به تلفن همراه و حيطههاى احساس

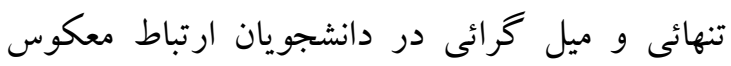

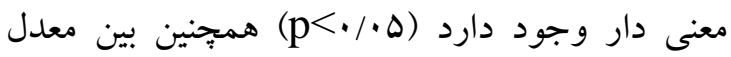
دانشجويان و اعتياد به تلفن همراه و حيطه هاى خلاقيت زدائى، احساس تنهائى و ميل گرائى ارتباط معكوس

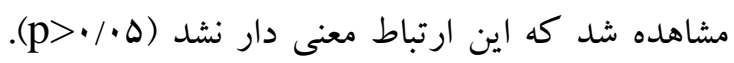
بين انكگيزه بيشرفت و معدل دانشجويان نيز ارتباط

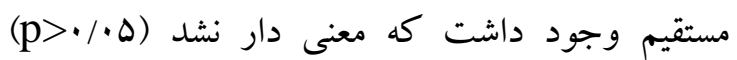
بيشترين ارتباط معنىدار بين اعتياد به تلفن همراه و سازه

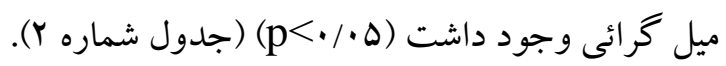
نتايج رگرسيون خطى تكك متغيره نيز نشان داد حدود 11 درصد از تغييرات انخيزه بيشرفت در دانشجويان با بان استفاده از متغير مستقل مدل يعنى اعتياد به تلفن همراه،

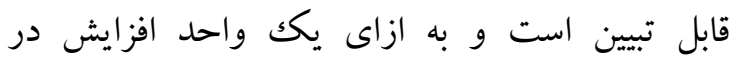

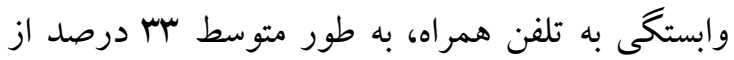

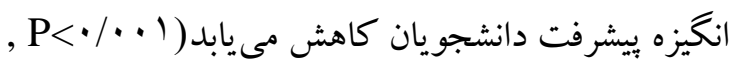
. $\left(\mathrm{R}^{2}=\cdot / 1\right), \mathrm{F}=\mathrm{rq} / 0 \mathrm{~d}$

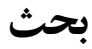
يثوهش حاضر با هدف بررسى رابطه بين اعتياد به تلفن

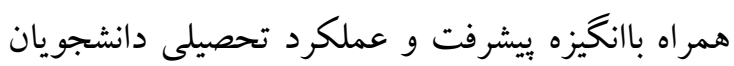
شهر خاش در سال تحصيلى 9V-9 آوانجام شد. مطالعه حاضر نشان داد كه سطح اعتياد به تلفن همراه در

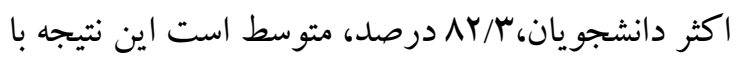
مطالعه منصوريان و همكاران (سوسا) كه به وضعيت اعتياد به تلفن همراه در دانشجويان علوم يزشكى تهران مى يرداخت همسو است. همجنين نتيجه مطالعه خزائى و

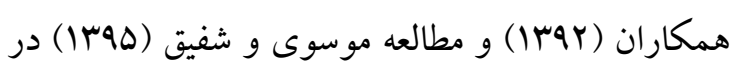
تهران با نتايج يزوهش حاضر از اين حيث يكسان است. حال آنكه اين نتايج بامطالعه يحيى زاده و همكاران 
اهداف اصلى خود يعنى توجه، ياد گيرى و يُزوهش دور مى ماند كه اين خود بر نتايج و عملكرد تحصيلى آنان تأثير منفى كذاشته و بالطبع اين نتايج وايين و كاها

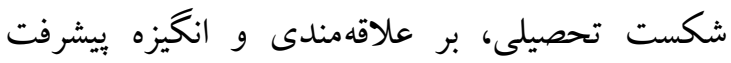

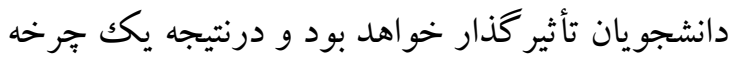
منفى شكل مى گيرد ( گنجى و همكاران، هوب1). نتايج مربوط به انگيزه بيشرفت دانشجويان نشان داد كه نمرات كسب شده اكثر دانشجويان در حد متوسط و ارتباط آن با عملكرد تحصيلى و معدل مثبت است كه اين نتايج با مطالعه مولازاده و همكاران (هوسا) كه به بررسى ارتباط بين انخيزه بيشرفت و موفقيت تحصيلى بـ مورد

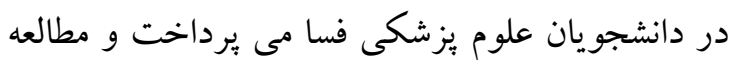
نوحى و همكاران (|ar|) هم خوانى دارد. طبق شواهد و مطالعات اين نتايج دور از انتظار نيست، انگيزه

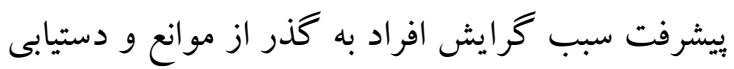
به معيارهاى ارزشمند مىشود (مولازاده و و همكاران، هَ|)؛ بنابراين براى تقويت انخيزه بيشرفت دانشجويان در تحصيل كه رابطه مستقيم با عملكرد و موفقيت تحصيلى آنان دارد عواملى مانند اعتياد به تكنولوزىهاى جديد و هوشمند مانند تلفن همراه مىبايست كنترل شود. مطالعه جن و همكاران (Y.IV) كه به بررسى تفاوت جنسيتى اعتياد به تلفن همراه در دانشجويان جين مى يرداخت نشان داد ميزان وابستگى در دانشجويان مرد بيشتر است و اين نتيجه با مطالعه حاضر همسو است.

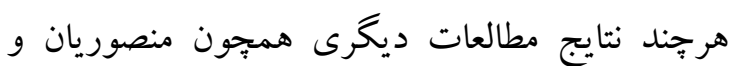
همكاران (سوس ا) و نيز مطالعه عابدينى و عشرت زمانى

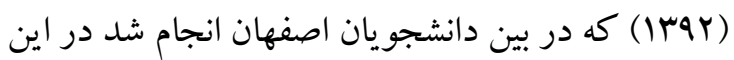
زمينه همسو با نتايج اين مطالعه نيست. عدم تفاوت در نتايج احتمال مىرود مربوط به متفاوت بودن شرايط

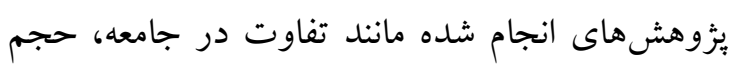
نمونه و ابزار سنجش باشد. در تبين بالاتر بودن سطح
دارد. همجِنين اين نتايج با مطالعه لِّب و همكاران (Y.|F)

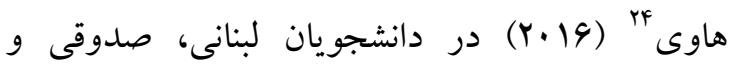
صالحى (M94) در دانشجويان يزشكى كاشان، هم خوانى دارد. از طرفى نتايج حاصل با مطالعه جالو كى دهاني

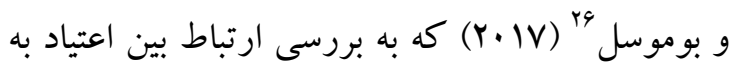
تلفن همراه هوشمند و عملكرد دانشجويان دانشگاه نوتردام لبنان يرداختند مغايرت دارد. در مطالعه آنان ارتباط معنى دار بين اين دو متغير يافت نشد. همجِنين

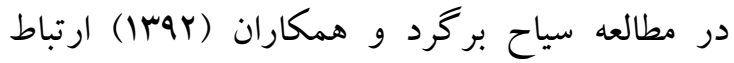
معنىدارى بين ميزان استفاده از تلفن همراه و موفقيت تحصيلى دانشجويان بزشكى مشاهده نشد (سياح بر گرد مدرد

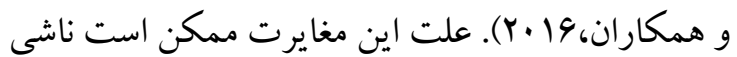
از تفاوت در شر ايط و محيط يزوهش باشد.

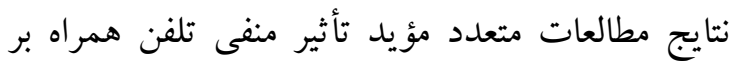
عملكرد تحصيلى دانشجويان مىباشند هرجند مطالعات اندكى به بررسى ييامدهاى استفاده مفرط از تلفن همراه بر انخيزه بيشرفت دانشجويان برداخته است اما در تبيين بردي

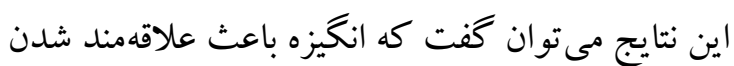
دانشجويان به مطالعه و يادگيرى در محيط دانشگاهى

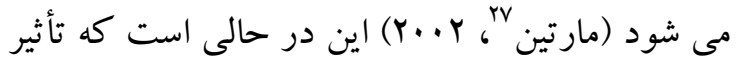

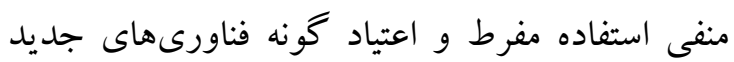
همجيون تلفن همراه هوشمند بر سلامت روان (صحبائى

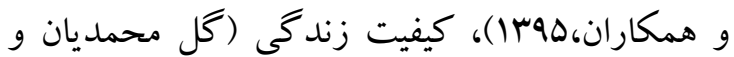

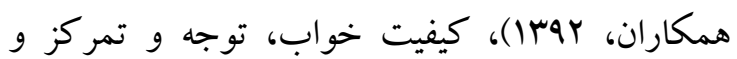
وظيفه شناسى دانشجويان بررسى و تائيد شده است (رضوى زاده و همكاران، وجا1). بنابراين دانشجويان معتاد به تلفن همراه هوشمند، طولانى مدت ذهن و و جسم خويش را درگير اين تكنولوزى كرده و از

\footnotetext{
${ }^{23}$ Samaha

${ }^{24}$ Hawi

${ }^{25}$ Jaalouk

${ }^{26}$ Boumosleh

${ }^{27}$ Martin
} 
شايان ذكر است كه تعارض منافع بين نويسند أنان اين يثزوهش وجود ندارد. اين مطالعه بخشى از طرح تحقيقات دانشجوئى مورد تائيد كميته اخلاق با كد IR.ZAUMS.REC.1397.184

$$
\text { علوم يزشكى زاهدان است. }
$$

\section{Refrences}

Abedini Y, Zamani B.(2013). Investigating motivation, type and rate of mobile use in university students.

Contemporary Psychology.7(2)7386.

Aram f b, E. Z., Zarghami M. (2016). Psychosocial damages caused by using mobile phonesInternet among students. Information and Communication Technology in Educational Sciences. 3: 111-130.

Ahmmad, M.(2006). The Effect of Motivation, Family Environment, and Student Characteristics on Academic Achievement. Recent Issues in Human Resource Management. 2(1):29-37

Akbari, B. 2009. The validity and reliability of test motivation for Hermann's progress on students. Knowledge and Research in Educational Sciences. 16:73-96.

Atadokht A, Hamidifar V, Mohammadi I.(2014) Over-use and type of mobile phone users in high school students and its relationship with academic performance and achievement motivation. J School Psychol.3(2):122-36.

Bianchi, A. PHilips, J. (2005).

Psychological Predictors of Problem Mobile Phone Use. CYBER PSYCHOLOGY \& BEHAVIOR. 8(1):39-51.

Billieux, J. Maurage, P. Lopez-Fernandez, O. Kuss, D.\& Griffiths, M. D. (2015). Can disordered mobile phone use be considered a behavioral addiction? An update on
وابستگى مردان نسبت به زنان دانشجو در منطقه 9. 9لوجستان (با توجه به اينكه در مطالعه حاضر بيش اله درصد دانشجويان داراى قوميت بلوج بودند) جنين مىتوان كفت كه در فرهنگك بلوج مردان از آزادى عمل بيشترى نسبت به زنان برخوردارند و انتظارات فرهنكى از زنان بيشتر است. نتيجه كيرى يافتها حاكى از آن است كه وابستكى اعتياد گونه به تلفن همراه بر انگيزه بيشرفت و عملكرد تحصيلى

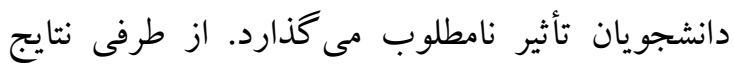
نشان داد در بيش از نيمى از دانشجويان سطح اعتياد به تلفن همراه متوسط است؛ بنابراين لازم است مسئولان

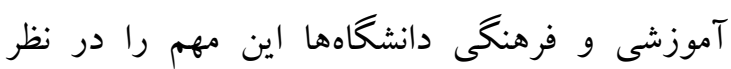
كرفته و ضمن بر گزارى كارگاههاى آموزشى جهت

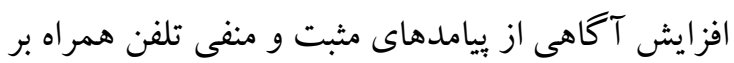

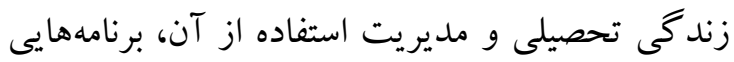
نيز جهت استفاده بهينه اوقات فراغت دانشجويان در منطقه خاش تدوين نمايند.

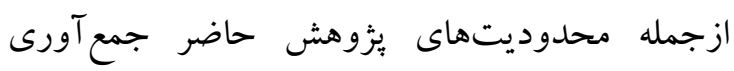

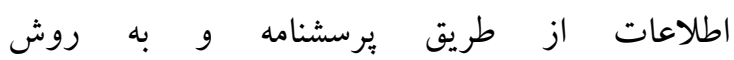
خودگزارشدهى بود كه ممكن است باعث شود برد دانشجويان غير متعهدانه يرسشنامهها را تكميل كنند

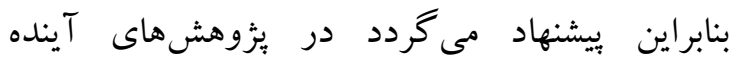
اطلاعات از طريق روشهايى همجيون مصاحبه جمع آورى و بررسى گردد همجنين با توجه به نتايج

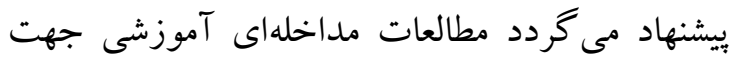
كاهش وابستكى افر اطى به تلفن همراه انجام شود.

$$
\text { تشكر و قدردانى }
$$

بدينوسيله از همكارى صميمانه تمامى دانشجويان حاضر در مطالعه تشكر و قدردانى به عمل مى آيد. 
Griffiths,M. 2000. Does Internet and Computer "Addiction" Exist?. CYBERPSYCHOLOGY \& BEHAVIOR.3(2).211-218.

Hiadarali, H., \& Askari, A. (2011). Preparation and standardization of the test of motivation for progress. Psychological research, 6(2), 9-33.

Hosainpoor A, Asgari A, Ayati M.(2016). The relationship between addiction to the Internet and mobile phone with students' academic burnout. Journal of Information and Communication Technologies in Education.;6(4):59-73 .

Ishii,K.(2011). Examining the adverse effects of mobile phone use among Japanese adolescents. Keio Communication Review.33:69-83.

Jenabbadi H. (2017). On the relationship between loneliness and social support and cell phone addiction among students. School Psychology, 5(4), 7-30

K, S. (2014). Build and Accelerate Mobile Addiction Inventory. Quarterly Journal of Educational Measurement, 4(15), 126-142 .

Khajeahmadi, M., Pooladi, S., \& Bahreini, M. (2016). Design and Assessment of Psychometric Properties of the Addiction to Mobile Questionnaire Based on Social Networks .

Khazaee, T. Saadatjoo, A. Shabani, M. Senobari, M \& Baziyan, M. (2013). Investigating the prevalence of mobile dependence and its relationship with student selfesteem. Journal of Science and Health, 8(4), Page: 156-162 .

Lepp, A. Barkley, JE. Karpinski, A C. (2014). The relationship between cell phone use, academic performance, anxiety, and Satisfaction with Life in college students. Computers in Human Behavior. 31:343-350.

Linnenbrink, E A. Pintrich, P R.(2002). Motivation as an Enabler for current evidence and a comprehensive model for future research. Current Addiction Reports. 2(2):156-162

Boumosleh J, Jaalouk D. (2017) Smartphone Addiction among University Students and Its Relationship with Academic Performance. Global Journal of Health Science. 10(1):48.

Chen, B. Liu, F.Ding, S. Ying, X. Wang, L.\& Wen, Y. (2017). Gender differences in factors associated with smartphone addiction: a crosssectional study among medical college students. BMC psychiatry, $17(1), 341$.

Chóliz, M. (2012). Mobile- phone addiction in adolescence: the test of mobilephone dependence (TMD). Progress in Health Sciences, 2(1), 33 .

Ezoe, S., \& Toda, M. (2013). Relationships of loneliness and mobile phone dependence with Internet addiction in Japanese medical students. Open Journal of preventive medicine, 3(06), 407 .

Gao, T. Li, J. Zhang, H. Gao, J. Kong, Y. Hu, Y.\& Mei, S. (2018). The influence of alexithymia on mobile phone addiction: The role of depression, anxiety and stress. Journal of affective disorders, 225, 761-766.

Ganji, B. Tavakoli,S. Baniasadi Shahr-e Babak3, F. Asadi, S. (2016). Surveying the relationship between internet addiction and Academic Engagement of students. EDCBMJ; 9(2): 150-155.

Golmohammadian, M., Yaseminejad, P \& Naderi, N. (2013). The relationship between cellphone over use and quality of life among students. Journal of Kermanshah University of Medical Sciences (J Kermanshah Univ Med Sci), 17(6), 387-393. 
Sahbaee F, shokri S, daemi M, \& M, p. (2017). Modeling of mobile phone and its relation with psychological state of Tehran university students . Scientific Journal of the Medical Council of the Islamic Republic of Iran.34(3).233-240.

Salehan, M., \& Negahban, A. (2013). Social networking on smartphones: When mobile phones become addictive .Computers in Human Behavior, 29(6), 2632-2639.

Sayyah bargard,M. Olapour A. Hoseini Ahangari, SA. Mashi, S F. Heidari A. 2016. Examine the Relationship Between Mobile Phone Usage and Psychological Health and Academic Success among Medical Students. Education Development Jundishapur. 7(1):57-63.

Sevari, K. (2014). Build and Accelerate Mobile Addiction Inventory. Quarterly Journal of Educational Measurement, 4(15), 126-142 .

Siyami, M. Rostami, SH. Salari,A.2018. Path Analysis of the Effect of Mobile Phone Use on AcademicEngagement of Students at Birjand University: The Mediating Role ofAttention. Educational Research.35: 72-92.

Tavakolizadeh J, Atarodi A, Ahmadpour S, Pourgheisar A. (2014)The prevalence of excessive mobile phone use and its relation with mental health status and demographic factors among the students of Gonabad University of Medical Sciences in 2011-2012. Razavi International Journal of Medicine.;2(1).

Yahyazadeh S, Fallahi-Khoshknab M, Norouzi K, Dalvandi A.(2017) The prevalence of smart phone addiction among students in medical sciences universities in Tehran 2016. Advances in Nursing \& Midwifery. 26(94):1-10.

Young, K. S., \& Rogers, R. C. (1998). The relationship between
Academic Success. School Psychology Review.31(3):313-327. Mansourian, M., Solhi, M., Adab, Z., \& Latifi, M. (2014). Relationship between dependence to mobile phone with loneliness and social support in University students. jornal of Razi .

Martin, A.J. (2002). Motivation and academic resilience: Developing a model of student enhancement. Australian Journal of Education, 46, 34-49.

Mosavi S, SHafigh Y. (2016).Addiction to Mobile in Tehran: A Sociological Study. Journal of Sociology of Iran.17(4):139-64.

Molazadeh AR, Hamaieli Mehrabani H, Gholami MS, Mortazavi AR, Dovlatkhah HR, Ghodsi R. (2014).Relationship of general health and improvement motivation with educational success among the students of Fasa University of Medical Sciences in 2013. J Neyshabur Univ Med Sci.2(4):5461

Momeni, H., \& Safdari, Z.(2016). Relationship between academic attitudeand achievement motivation with students' perception of the quality of curriculum.Higher Education Curriculum Studies, 7(13), 101-121 .

Nohi S, Hosaini S, Rokhsari zadeh $\mathrm{H}$, Sabori A \& Alishiri G. H. (2012). Studying the motivation ofprogress and its relationship with academic achievement in medical, nursing and medical students in a medical university. Journal of Military Medicine, 14(3), 200-204.

Razavizadeh SH, Parandeh A, RahmatiNajarkolaei F. (2018).Pathology of Mobile Phone use in Military University Students from theViews of Media and Communications professionals. Journal of Military Medicine.19(6):595-606. 
$25-28$

depressionand Internet addiction.

Cyberpsychology \& behavior, 1(1),

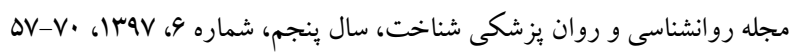

